\title{
Intervensi Kemanusiaan dalam Studi Hubungan Internasional: Perdebatan Realis Versus Konstruktivis
}

\author{
Mohamad Rosyidin
}

Universitas Diponegoro

\begin{abstract}
ABSTRAK
Artikel ini bermaksud memetakan isu intervensi kemanusiaan dalam konteks teoritis. Dua perspektif utama berdiri secara diametral dalam memandang intervensi kemanusiaan yaitu realisme dan kontruktivisme. Realisme, di satu sisi, memandang bahwa intervensi kemanusiaan tak lebih dari instrumen diplomasi untuk mengejar kepentingan nasional. Mengingat realisme tidak menaruh kepercayaan terhadap prinsip-prinsip abstrak dalam memandu kebijakan luar negeri, mereka bersikukuh bahwa intervensi kemanusiaan murni tindakan politis. Di sisi lain, konstruktivisme memandang sebaliknya bahwa intervensi kemanusiaan berhubungan erat dengan sifat negara yang mematuhi peraturan dan norma internasional. Konstruktivisme percaya bahwa terlepas dari adanya kepentingan nasional di balik tindakan negara, intervensi kemanusiaan merupakan upaya komunitas internasional untuk menegakkan norma kemanusiaan. Alhasil, berbeda dengan realis yang menganggap negara adalah aktor yang mementingkan diri sendiri konstruktivis menganggap negara adalah aktor altruis yang memiliki kepedulian terhadap warga negara lain.
\end{abstract}

Kata-kata kunci: intervensi kemanusiaan, realisme, konstruktivisme

This article presents the debate between realists and constructivists over the issue of humanitarian intervenstion focusing on its theoretical foundations. The article seeks to fill the gap by highlighing on two contending perspectives of International Relations; realism and constructivism. On the one side, realists argue that humanitarian intervention is nothing but the diplomatic instrument of foreign policy conducted to achieve the national interest. It, however, does not have to follow in the abstract principles. Realists stress that humanitarian intervention is political in itself. On the other side, constructivists stand by the nature of states' attitude to comply with international rules and norms. They argue against the realists' penchant to the national interest behind foreign policy action. Humanitarian intervention is construed as the act of states to uphold humanitarian norms in the international community. Finally, constructivists consider the state as an altruist actor caring about foreigners oppsing the realist view of the state's self help oriented policy.

Keywords: humanitarian intervention, realism, constructivism 
Kajian mengenai intervensi militer yang dimaksudkan untuk tujuan kemanusiaan atau 'intervensi kemanusiaan' dalam studi Hubungan Internasional dapat dikatakan masih kurang. Hal ini dikarenakan isu ini masih relatif'baru'. Intervensi kemanusiaan mencuat menjadi isu internasional saat Amerika Serikat menginvasi Somalia pada tahun 1992 dalam kasus pendongkelan rezim militer Mohammad Farrah Aideed. Peristiwa yang kemudian terkenal dengan sebutan 'Black Hawk Down' ini menjadi preseden bagi tindakan negara mengirim tentara ke wilayah yurisdiksi negara lain tanpa seizin negara bersangkutan. Meski tanpa ijin tuan rumah, intervensi internasional mendapat mandat dari organ yang lebih tinggi yakni PBB.

Seperti dicatat Morgenthau (1967), sejarah campur tangan negara lain dengan melibatkan kekuatan militer sudah berlangsung sejak lama. Intervensi merupakan instrumen kebijakan luar negeri yang umurnya sama tuanya dengan instrumen lain seperti tekanan diplomatik, negosiasi dan perang. Apa yang membedakan hanyalah tujuan-nya, sedangkan cara-nya tetap sama yakni dengan instrumen militer. Berbicara mengenai tujuan tentu saja berbicara tentang kepentingan negara. Tujuan atau kepentingan ini sungguh terkait erat dengan konsepsi negara. Konsepsi inilah yang acapkali mengalami perubahan alih-alih kontinyuitas. Itulah sebabnya kenapa konsep kepentingan yang terkandung dalam intervensi militer berbeda dari waktu ke waktu. Setelah Perang Dingin usai, intervensi militer lebih didominasi konsepsi tentang kepentingan kemanusiaan.Beberapa kasus intervensi militer antara lain Haiti (1993), Kosovo (1995), Rwanda (1995), Timor-Timur (1999), dan baru-baru ini Libya.

Intervensi kemanusiaan lebih banyak dikaji dari sudut pandang Hukum Internasional ketimbang Hubungan Internasional. Ini tidak mengherankan karena tindakan ikut campur negara terhadap urusan domestiknegara lain dilegitimasi oleh Piagam PBB khususnya Bab 7. Aturan perihal tanggung jawab internasional terhadap kemanusiaan juga bisa ditemukan dalam Konvensi Jenewa mengenai pasal hak asasi manusia. Sedangkan dalam kacamata Hubungan Internasional, intervensi ekuivalen dengan perang sehingga dikaitkan dengan kepentingan negara agresor. Sudut pandang realis ini kemudian mendapat tantangan serius dari para penganut mazhab konstruktivisme yang menitikberatkan pada masalah norma.

Perdebatan teoritis mengenai masalah intervensi kemanusiaan berkutat di seputar isu legal, moral dan politis. Persoalan yang menjadi perdebatan adalah terkait klaim legitimasi tindakan tersebut. Ini biasanya identik dengan pertanyaan seperti kapankah suatu intervensi militer dipandang sebagai intervensi kemanusiaan? (Holzgrefe \& Keohane 2003). Isu intervensi kemanusiaan juga berkaitan dengan perdebatan mengenai konsep kedaulatan. Bagaimana mungkin negara 
yang kedaulatannya dijamin hukum internasional bisa dicampuri oleh negara lain? Argumennya adalah bahwa kedaulatan tidak bersifat tak terbatas (Shue dalam Welsh 2004). Persoalan ini lebih menyentuh aspek filosofis ketimbang politis. Sedangkan pakar yang lain menyatakan bahwa kedaulatan bisa menjadi sebuah tanggung jawab (sovereignty as responsibility) dikarenakan kepatuhan negara-negara kepada norma internasional (Wheeler dalam Welsh 2004). Agaknya tesis ini sejalan dengan tesis konstruktivis yang juga menggunakan norma internasional sebagai batu pijakan dalam menjelaskan intervensi kemanusiaan.

Artikel ini bermaksud memetakan isu intervensi kemanusiaan dalam konteks teoritis. Seperti disebutkan di atas, literatur mengenai masalah ini lebih banyak bernuansa legal-etis-filosofis-formal yang sarat akan aspek hukum internasional ketimbang hubungan internasional. Memang diakui, jika kita hendak mengkaji masalah intervensi militer kita tentu tidak bisa melepaskan diri dari kerangka hukum internasional. Tetapi jika kita berpijak pada landasan legal-formal hukum internasional, pendekatan seperti itu tidak banyak memberikan kontribusi terhadap kemajuan ilmiah Hubungan Internasional yang menjadi disiplin ilmu yang berdiri sendiri. Daripada memperdebatkan dikotomi legal/tidak legal atau etis/tidak etis yang menjadi subject matter hukum internasional dan demi alasan kegunaan analitis dalam disiplin hubungan internasional, sebaiknyakita memfokuskan pada masalah motif atau alasan dibalik intervensi kemanusiaan.

Artikel ini akan mengikuti sistematisasi sebagai berikut: bagian pertama akan menjelaskan konsep intervensi kemanusiaan. Setidaknya ada dua jenis intervensi yakni intervensi militer dan intervensi kemanusiaan. Intervensi militer belum tentu melibatkan isu kemanusiaan, tetapi intervensi kemanusiaan seringkali didahului oleh intervensi militer.Intervensi kemanusiaan juga dibedakan dari operasi kemanusiaan (humanitarian action). Bagian kedua akan menjelaskan intervensi kemanusiaan menurut sudut pandang realis. Realis berasumsi bahwa intervensi militer sekalipun untuk alasan kemanusiaan adalah instrumen politik luar negeri. Karena negara itu egois - mementingkan diri sendiri atau self help - maka intervensi militer dilatarbelakangi oleh motif individualis yakni demi kepentingan nasional. Bagian ketiga akan menjelaskan intervensi kemanusiaan dari sudut pandang konstruktivis. Para penganut konstruktivis berpendapat bahwa intervensi bukan didorong oleh kepentingan individualis negara tertentu, melainkan etikat negara untuk tunduk pada norma internasional. Bagian keempat atau terakhir adalah kesimpulan. 


\section{Konsep Intervensi Kemanusiaan}

Intervensi kemanusiaan merupakan subyek yang banyak mengandung kontroversi dan membingungkan (Heinze 2009, 7). Kontroversial karena: pertama, intervensi kemanusiaan secara konseptual jelas-jelas kontradiktif dengan konsep kedaulatan. Dalam sejarah relasi antar bangsa, konsep kedaulatan yang diterima adalah konsep kedaulatan Westphalia. Konsep ini lahir sebagai konsekuensi perjanjian damai Westphalia pada tahun 1648 yang intinya adalah setiap entitas politik yang disebut negara berhak mengatur urusannya sendiri tanpa campur tangan pihak lain (non-interference). Prinsip ini kemudian dituangkan dalam Piagam PBB Bab2 (Pasal 7) yang melarang negara lain ikut campur urusan dalam negeri negara lain. Kedua, intervensi kemanusiaan kontradiktif dengan prinsip larangan penggunaan kekuatan militer (non-use of force). Prinsip ini termaktub secara eksplisit dalam Piagam PBB Bab2 (Pasal 4) yang isinya melarang penggunaan kekuatan militer kecuali untuk pertahanan diri (selfdefense) atau atas ijin DK PBB (Bellamy dalam Wiliams 2008, 423). Mengingat perdebatan tentang hal ini merupakan substansi hukum internasional, tulisan ini tidak akan memfokuskan pada isutersebut.

Para sarjana Barat umumnya sepakat mengenai definisi intervensi kemanusiaan. Intervensi kemanusiaan dipahami sebagai "pengerahan pasukan militer ke negara lain demi tujuan melindungi warga negara lain dari kekerasan" (Finnemore 2003, 53). Definisi yang lebih komprehensif dikemukakan oleh Holzgrefe (dalam Holzgrefe \& Keohane 2003,18 ) yakni "ancaman atau penggunaan kekuatan militer di wilayah kedaulatan negara lain oleh satu negara (atau sekelompok negara) yang dimaksudkan untuk mencegah dan menghentikan kekerasan terhadap hak asasi manusia individu ketimbang warga negaranya sendiri dengan tanpa seijin negara yang diberikan tindakan militer tersebut”. Definisi ini tampak sejalan dengan definisi yang dikemukakan oleh Heinze $(2009,7)$ yakni "penggunaan kekuatan militer oleh satu atau sekelompok negara di dalam wilayah yurisdiksi negara lain, tanpa seijin negara yang bersangkutan, untuk tujuan mencegah atau menghentikan penindasan terhadap warga negara yang dilakukan oleh negara itu. Sedangkan Welsh $(2004,3)$ mendefinisikan intervensi kemanusiaan sebagai tindakan "campur tangan koersif dalam urusan internal negara lain yang melibatkan penggunaan kekuatan militer untuk mencegah kekerasan terhadap hak asasi manusia atau mencegah meluasnya penderitaan yang dialami warga."

Dari beberapa definisi konseptual mengenai istilah intervensi kemanusiaan di atas, dapat disimpulkan bahwa intervensi kemanusiaan paling tidak mengandung tiga unsur pokok: penggunaan kekuatan militer (metode), penghentian pelanggaran terhadap hak asasi manusia (tujuan), dan dilakukan tanpa seijin negara yang bersangkutan 
(prosedur). Definisi ini berbeda dengan konsep intervensi militer dimana negara menggunakan cara koersif - kekuatan militer, sebagaimana namanya - untuk menghukum negara lain karena dianggap membahayakan keamanan internasional tanpa disertai dengan upaya-upaya kemanusiaan (humanitarian relief). Di sini penekanan intervensi militer hanya pada metode yang ditempuh, bukan tujuan yang hendak dicapai.

Intervensi kemanusiaan hendaknya juga dibedakan dari konsep operasi kemanusiaan (humanitarian action). Jika intervensi kemanusiaan acapkali menggunakan metode koersif, operasi kemanusiaan menggunakan metode non-koersif atau nir-kekerasan. Hehir $(2010,12)$ mengatakan bahwa humanitarianisme dan operasi kemanusiaan adalah istilah yang kerap digunakan para pekerja kemanusiaan dan organisasi non-pemerintah dimana istilah kemanusiaan diartikan sebagai tindakan yang altruistik, non-politis, dan hirau dengan kemaslahatan orang banyak. Operasi kemanusiaan biasanya dilakukan oleh organ-organ non-pemerintah (NGO) internasional seperti organisasi PBB yang mengurusi masalah pengungsi (UNHCR), Organisasi Palang Merah Internasional (ICRC) dan sebagainya. Tetapi negara terkadang juga ikut terlibat dalam menyelenggarakan aktivitas-aktivitas kemanusiaan seperti kesehatan, penyaluran bahan pangan, rekonstruksi infrastruktur, pendidikan dan lain-lain.

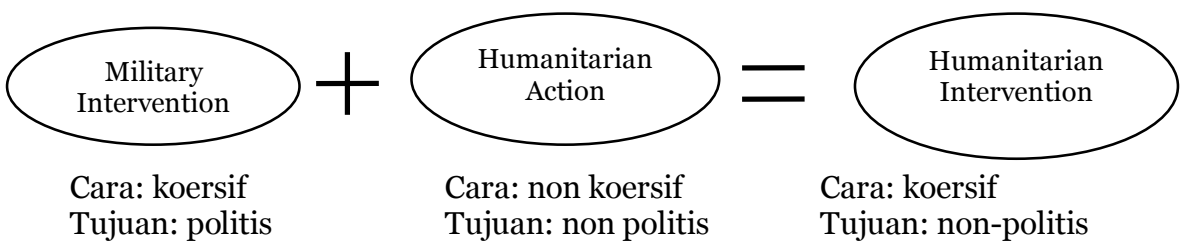

Landasan moral bagi intervensi kemanusiaan lahir dari sejarah peradaban Barat. Para ahli kerap merujuk landasan moral ini pada Just War Theory atau diartikan sebagai 'teori tentang perang yang dapat dibenarkan'. Menurut teori ini, perang atau penggunaan kekerasan hanya dibenarkan sejauh menyangkut dua hal yakni untuk membela diri dan menghukum pihak yang telah melakukan kesalahan. Dalam konteks intervensi kemanusiaan, prinsip kedua menjadi landasan moral yang menjadikannya dapat dibenarkan. Thomas Aquinas, filsuf-rohaniawan Abad Pertengahan mencetuskan ide tentang Just War dalam bukunya Summa Theologicae (Summary of Theology) mengatakan bahwa alasan yang dapat dibenarkan untuk memerangi orang lain adalah "Mereka yang melakukan penyerangan harus diperangi karena mereka berhak mendapatkannya atas kesalahannya" (Nardin 2000). Memerangi yang tidak bersalah adalah dosa sehingga menghukum mereka yang 
melakukannya adalah suatu tindakan yang dibenarkan. Sedangkan Onuf (2000) berpendapat bahwa konsep intervensi kemanusiaan yang kita kenal dewasa ini pada mulanya adalah gagasan untuk menata dunia menurut 'sensibilitas liberal'. Pelanggaran hak asasi manusia dipandang sebagai upaya merusak tatanan masyarakat liberal sehingga diperlukan tindakan campur tangan untuk mengembalikan tatanan itu.

\section{Egoisme Negara: Intervensi Kemanusiaan dalam Perspektif Realis}

Intervensi kemanusiaan menantang premis dasar realisme tentang konsep keamanan. Keamanan dalam sudut pandang realis dimaknai sebagai keamanan tradisional yakni kemanannegara (states security). Studi keamanan adalah studi tentang perang dan diplomasi yang sangat kental dengan urusan negara (Kolodziej 1992). Walt (1991) merangkum gagasan tentang studi keamanan sebagai "studi tentang ancaman, penggunaan dan pengendalian kekuatan militer."Penggunaan sarana militer ini tentu saja adalah otoritas negara sehingga negara adalah unit analisis primer yang menjadi sasaran ancaman atau referent object (Buzan \& Hansen 2009, 11). Realis mengakui keamanan dalam arti nontradisional (non-traditional security) seperti perubahan iklim, wabah penyakit, kemiskinan, krisis ekonomi dan kejahatan terhadap hak asasi manusia. Tetapi seperti dikatakan Lynn-Jones (1991), isu keamanan non-tradisional tersebut masuk ke dalam ranah studi keamanan hanya jika memberikan dampak langsung terhadap keamanan negara sebagai unit analisis utama.Sedangkan intervensi kemanusiaan hirau dengan isu keamanan non-tradisional yakni keamanan manusia (human security). Isu ini menjadi salah satu isu penting dalam studi keamanan dan menantang keterbatasan ruang lingkup studi keamanan tradisional yang hanya berkutat pada masalah keamanan negara (Buzan 1991; Buzan, Waever \& Wilde 1998; dan Buzan \& Hansen 2009).

Konsep intervensi kemanusiaan juga menantang konsep moral dalam hubungan internasional. Moralitas adalah konsep sosiologis yang bermakna baik atau buruk. Intervensi kemanusiaan seringkali diklaim sebagai upaya untuk menegakkan kebaikan dan mengalahkan kejahatan. Intervensi koalisi Perancis, Inggris, dan Amerika Serikat di Libya pada bulan Maret 2011 dikatakan sebagai cara untuk melindungi hak asasi manusia warga sipil Libya dari kejahatan rezim Khadafi. Tetapi dalam ranah politik, kategori tindakan baik/buruk tentulah sangat subyektif. Pihak yang paling kuatlah yang berperan besar menciptakan kategorisasi baik/buruk ini.

Realisme sangat 'alergi' dengan masalah moralitas. Ini karena akar pemikiran realis didasarkan pada pemikiran tentang hakekat politik 
yang sepenuhnya pesimistis. Bagi para penganut realisme, tidak ada moralitas dalam politik dan tentu saja politik internasional. Morgenthau $(1954,9)$ mengemukakan salah satu dari enam prinsip dasar realisme yaitu "prinsip-prinsip moralitas universal tidak bisa diaplikasikan dalam tindakan negara." Absennya moralitas diklaim berakar dari sifat dasar (state of nature) manusia yang mempunyai sifat jahat dalam dirinya. Seperti dikemukakan pemikir realpolitik termasyhur Machiavelli bahwa "harus diterima kenyataan bahwa manusia itu jahat dan selalu akan menggunakan kelicikan yang ada dipikirannya setiap ada kesempatan" (Donnely 2000, 9). Selain jahat, manusia juga mempunyai perangai mementingkan diri sendiri (egois). Mengenai hal ini, para penganut mazhab realisme sepakat tentang karakter egoistik dan mementingkan diri sendiri dalam politik internasional. Pandangan negatif dan pesimistis tentang sifat manusia tersebut menjadi ciri khas paradigma realisme dalam politik internasional.

Tantangan terbesar isu intervensi kemanusiaan kaitannya dengan paradigma realis adalah tentang konsep kepentingan nasional (national interest). Bagi realis, kepentingan nasional adalah faktor utama tindakan negara. Semua tindakan negara selalu dipandu oleh kepentingan nasional. Karena hakekat manusia adalah egois, maka negara pun demikian. Negara akan bertindak semata-mata karena memperjuangkan kepentingan dirinya sendiri. Waltz (1979, 88) menegaskan bahwa karakter anarki politik internasional memaksa negara untuk bertindak seragam (like unit) dengan hanya memfokuskan pada prinsip menolong diri sendiri (self help). Dalam hubungan internasional, negara adalah aktor privat yang memandang tidak ada kepentingan yang lebih tinggi daripada kepentingannya sendiri ( $\mathrm{Lu}$ 2006, 39).

Intervensi kemanusiaan bagi realis bukan didasari oleh motivasi untuk memperjuangkan kepentingan keamanan internasional. Intervensi kemanusiaan adalah upaya untuk memperjuangkan kepentingan negara pengintervensi. Dalam hal ini, definisi intervensi kemanusiaan sesuai dengan pendapat Bellamy $(2003,10)$ bahwa jika negara bertindak atas dasar kepentingan dirinya, maka intervensi kemanusiaan adalah upaya negara kuat untuk melawan negara lemah dengan kekuatan militer demi kepentingannya sendiri. Negara melakukan tindakan intervensi bukan semata-mata untuk alasan kemanusiaan karena negara senantiasa didorong oleh kepentingan nasional (Wheeler 2000, 30). Alhasil, negara tidak akan rela bersusah payah mengintervensi negara lain hanya untuk membela kepentingan selain kepentingan nasionalnya. Bellamy dan Wheeler (dalam Baylis \& Smith 1998) menegaskan bahwa kaum realis tidak hanya berangkat dari asumsi bahwa negara tidak melakukan intervensi untuk maksud kemanusiaan tetapi juga negara tidak perlu bertindak melalui cara ini. Pemimpin politik tidak punya hak moral untuk menumpahkan darah warga negaranya sendiri demi menolong 
orang asing. Singkatnya, intervensi kemanusiaan tak lebih daripada alat kebijakan luar negeri negara pengintervensi (Krieg 2013, 43).

Masalahnya di sini adalah keterbatasan realisme mengenai konsep kepentingan nasional. Realisme hanya mengakui kepentingan nasional dalam segi material, baik militer maupun ekonomi. Sebagaimana dikatakan Burchill (2005, 47), "ideologi-ideologi dominan, agama, caracara produksi dan lembaga-lembaga sosial bagi realis hanya memberikan pengaruh kecil terhadap perilaku negara.” Kepentingan militer biasanya bersifat geostrategis, artinya letak suatu wilayah dianggap bisa memberikan keuntungan strategis bagi negara, misalnya menginvasi negara lain untuk membangun pangkalan militer atau mengokupasi wilayah tertentu untuk memberikan kemudahan dalam mengawasi atau menyerang negara lain. Amerika Serikat merupakan negara yang memiliki pangkalan militer terbesar di dunia yang mana mampu menjangkaukawasan di seluruh dunia. Sedangkan kepentingan ekonomi lebih bersifat geoekonomi, yakni letak suatu wilayah yang dianggap menguntungkan secara ekonomis misalnya dalam kasus invasi Amerika Serikat ke Irak tahun 2003 didorong oleh hasrat untuk mengontrol produksi minyak di negara tersebut.

Namun seringkali kita melihat kepentingan nasional suatu negara tidak terbatas pada masalah materi semata, tetapi hal-hal yang bersifat ide/gagasan. Contohnya adalah Uni Soviet pada masa Perang Dingin dengan program Komintern yaitu kebijakan Josef Stalin mengeksporideologi Komunisme ke seluruh dunia. Sebagai respon Amerika Serikat di bawah pemerintahan Harry S. Truman mengeluarkan kebijakannya yang terkenal yaitu Doktrin Truman sebagai strategi pembendungan (containment policy) komunisme. Sebagai kompetitor ideologis, Amerika Serikat tercatat sebagai negara yang paling banyak mendalangi upaya kudeta untuk mengganti rezim yang menentang dia dengan demokrasi, misalnya penggulingan Mossadeq di Iran, Salvador Allende di Chili, Ali Bhutto di Pakistan, termasuk kudeta 1965 di Indonesia yang menggulingkan presiden Sukarno (Blum 2002).

Realisme menganggap realitas kepentingan nasional yang bersifat nonmaterial ini sebagai epifenomena - ada tetapi keberadaannya tidak memberikan pengaruh - dalam politik internasional dan hanya mengakui kapabilitas material relatif sebagai determinan kebijakan luar negeri suatu negara. Kapabilitas material relatif ini memang penting, namun tidak begitu berarti dalam menjelaskan kepentingan AS dalam rangka menyebarluaskan demokrasi ke seluruh dunia. Monten (2005, 118) mengatakan, "kapabilitas untuk menggunakan kekuatan politik dan militer jelas merupakan prasyarat bagi upaya menyebarluaskan demokrasi ke seluruh dunia, namun tidak semua negara yang memiliki kapabilitas ini melakukan kebijakan penyebarluasan demokrasi." 
Misi mempromosikan demokrasi sebagai identitas nasional Amerika memang lebih bernuansa liberal daripada realis. Tetapi strateginya menggunakan cara-cara realis yaitu penggunaan instrumen militer. Intervensi yang sering dilakukan Amerika Serikat dalam sejarah berupa pengerahan militer ke suatu wilayah bukan untuk latihan tetapi sematamata mencerminkan kepentingan nasionalnya (Hippel 2004, 3). Mantan menteri luar negeri Amerika Serikat Condoleeza Rice $(2008,4)$ menandaskan dalam artikelnya bahwa "bagi Amerika Serikat, mempromosikan demokrasi ke seluruh dunia harus menjadi prioritas utama”. Pernyataan ini menggarisbawahi politik luar negeri Amerika Serikat yang mengutamakan kepentingan untuk membuat dunia menganut sistem politik demokratis yang dianggap sebagai ideologi final dan universal (Fukuyama 1992).

Politik luar negeri suatu negara senantiasa dituntun oleh doktrin; semacam pemikiran yang memberikan arahan tentang apa yang harus dilakukan dan apa yang tidak oleh negara. Doktrin politik luar negeri Amerika Serikat dapat dikategorikan menjadi beberapa aliran. Kissinger $(1994,18)$ membagi doktrin politik luar negeri Amerika Serikat menjadi dua aliran: isolasionis dan misionaris. Di kancah internasional, Amerika Serikat memainkan peran ganda sebagai 'mercusuar'(beacon) dan 'tentara salib' (crusader). Amerika Serikat menganut demokrasi dan oleh karena itu seolah-olah ia adalah pemberi petunjuk (mercusuar) bagi negara-negara lain. Nilai yang dianutnya itu kemudian melahirkan prinsip bahwa Amerika Serikat bertanggung jawab untuk memaksakan nilai tersebut ke seluruh dunia. Justifikasi peran internasional Amerika Serikat adalah mesianistik: Amerika Serikat punya kewajiban, bukan demi keseimbangan kekuasaan, tetapi untuk menyebarluaskan prinsip yang dianutnya ke seluruh dunia (Kissinger 1994, 26).

Pendapat lainnya dikemukakan oleh Francis Fukuyama. Dalam bukunya Fukuyama $(2006,7)$ membagi doktrin politik luar negeri Amerika Serikat menjadi empat aliran: neokonservatif, realis, liberal internasionalis, dan nasionalis 'Jacksonian'. Neokonservatisme merupakan aliran dalam politik luar negeri Amerika Serikat yang relatif baru. Aliran ini muncul sebagai doktrin kebijakan luar negeri setelah Robert Kagan dan William Kristol menulis artikel dalam majalah Foreign Affairs pada 1996. Dalam tulisannya, Kagan dan Kristol memberikan landasan kebijakan luar negeri Amerika Serikat yang berpedoman pada tiga hal yakni ekspansionisme, intervensionisme, dan mempromosikan demokrasi. Doktrin ini serupa dengan doktrin mesianistik Wilsonian menurut terminologi Kissinger dan 'Realisme Baru'-nya Condoleeza Rice. Menurut doktrin ini, peran aktif di kancah internasional mencerminkan kepentingan nasional Amerika Serikat. Kagan dan Kristol (dalam Fukuyama 2006, 40) menggarisbawahi bahwa 'hegemoni demi kebaikan' di bawah kepemimpinan Amerika Serikat adalah upaya untuk "menahan, dan jika memungkinkan mencegah 
munculnya diktator-diktator dan ideologi-ideologi mengancam; ... mendukung kepentingan Amerika dan prinsip-prinsip demokrasi; dan ... memberikan bantuan bagi mereka yang berjuang melawan sifat jahat manusia yang lebih ekstrim.”

Landasan politik luar negeri yang demikian itu dimanifestasikan dalam bentuk kebijakan 'pergantian rezim' (regime change) dalam rangka memaksa pemerintahan tiran dan despotis untuk tunduk pada nilai yang digariskan Amerika Serikat. Pemerintahan George W. Bush dengan tegas menyatakan bahwa garis kebijakan luar negerinya adalah mengikis habis rezim-rezim non-demokratis yang menentang negaranya. Sebagaimana Jervis (2003, 367) mengatakan, “...pergantian rezim diperlukan sebab pemerintahan tirani akan senantiasa mengabaikan perjanjian serta mengancam tetangga-tetangganya sebagaimana mereka memperlakukan warga negaranya dengan tidak layak."Pasca peristiwa 11 September 2001 kita melihat bagaimana Amerika Serikat menginvasi Afganistan dan menumpas habis rezim Taliban serta menggantinya dengan rezim boneka Hamid Karzai. Tidak lama setelah itu, Amerika Serikat melanjutkan petualangan mesianistiknya mendongkel rezim tiran Saddam Hussein di Irak dan memasang Jalal Talabani sebagai presidennya.

Intervensi kemanusiaan Amerika Serikat dan koalisi di Libya pada 2011pada dasarnya adalah upaya mengganti rezim Khadafi yang dianggap tidak ramah terhadap negara-negara barat. Amerika Serikat menemukan momentum itu ketika Libya dilanda revolusi politik yang berlarut-larut oleh kaum pemberontak yang didukung barat. Demokratisasi ternyata tidak berjalan mulus seperti yang terjadi di Tunisia dan Mesir dimana demonstran anti pemerintah berhasil menggulingkan rezim Ben Ali dan Mubarak. Alih-alih mundur, Khadafi justru memberangus kelompok anti pemerintah dengan kekerasan. Situasi ini membuat DK PBB terpaksa mengambil langkah tegas. Tiga anggota tetap (Inggris, Perancis, dan Amerika Serikat) minus Rusia dan Cina yang mengambil keputusan abstain mengeluarkan resolusi untuk menggelar operasi militer terhadap Libya dengan satu misi: menyelamatkan warga sipil yang menjadi korban penindasan rezim Khadafi.

Intervensi kemanusiaan di Libya adalah sebuah paradoks (Finnemore dalam Price 2008). Serangan koalisi ke negara itu justru mengakibatkan jatuhnya korban jiwa di kalangan sipil. Pada serangan tanggal 20 Maret 2011 serangan NATO membunuh 48 warga sipil Libya (Viva News 2011). Serangan militer itu membuktikan bahwa motivasi pasukan koalisi tidak lagi bersifat kemanusiaan, tetapi politis. Setelah NATO mengambil alih serangan, korban sipil terus berjatuhan. Pada tanggal 13 Mei 2011, serangan tentara NATO menewaskan 16 warga sipil Libya dan melukai sedikitnya 40 orang di kota Brega, Libya Timur (Antara News 2011). 
Bukti lain jika serangan ke Libya bukan bermotif kemanusiaan adalah NATO menolak tawaran negosiasi dari pemimpin Libya Moammar Khadafi (Republika 2011). NATO meragukan kredibilitas tawaran damai tersebut. Penolakan barat tersebut bisa dikategorikan sebagai pengabaian terhadap upaya damai. Bagi negara-negara barat, upaya damai tidak ada gunanya jika Khadafi belum berhasil digulingkan dan menggantinya dengan rezim demokratis.

\section{Altruisme Negara: Intervensi Kemanusiaan dalam Perspektif Konstruktivis}

Konstruktivisme memandang dunia secara berbeda dengan realisme. Jika realisme lebih mementingkan aspek material, konstruktivisme menekankan pada aspek non-material. Realisme mengklaim bahwa benda mati (fakta kasar) seperti kekuatan militer dan ekonomi negara menentukan tindakan negara. Konstruktivisme menantang cara pandang itu bahwa karena hubungan internasional adalah masalah sosial, maka determinan tindakan negara adalah pemahaman bersama (shared understanding) atau meminjam terminologi Alexander Wendt sebagai intersubyektivitas (Wendt 1992\& 1999). Intersubyektivitas berarti tindakan aktor dalam hubungan internasional tidak serta-merta derivasi dari kepentingan yang inheren dan sudah seperti itulah adanya dan seharusnya (given), tetapi produk dari proses pemaknaan aktor tersebut.

Dalam menjelaskan fenomena internasional, konstruktivisme berpijak pada kata kunci norma. Norma dipahami sebagai "harapan-harapan kolektif mengenai perilaku yang pantas bagi aktor dengan identitas tertentu" (Jepperson, Wendt \& Katzenstein dalam Katzenstein 1996, 54). Norma membantu mendefinisikan situasi dan oleh karena itu mempengaruhi interaksi antar negara (Zehfuss 2004, 4). Finnemore (1996a, 2) lebih jauh menjelaskan bahwa kepentingan negara didefinisikan dalam konteks nilai dan norma internasional. Aktor-aktor hubungan internasional terutama negara melakukan tindakan karena dituntun oleh aturan-aturan, prinsip-prinsip, norma yang disepakati bersama, serta keyakinan yang kesemuanya ini menyediakan pengertian tentang apa yang penting, berharga, baik dan apa cara-cara yang efektif atau legitimate dalam rangka mencapai hal-hal tadi (Finnemore 1996a, 15). March dan Olsen $(2004,3)$ berpendapat bahwa peraturan dan norma diikuti sebab sudah terlanjur dianggap alami, benar, dikehendaki, dan sah. Aktor-aktor internasional melakukan tindakan yang mereka anggap pantas untuk dilakukan berdasarkan peraturan dan norma tersebut. Jadi konstruktivisme tidak peduli dengan masalah kepentingan yang menyetir kebijakan negara akan tetapi apa yang membentuk kepentingan dan bagaimana kepentingan itu terbentuk. 
Norma berfungsi sebagai penuntun perilaku (regulatif) negara sekaligus membentuk identitas (konstitutif) negara. Di satu pihak, norma secara intrinsik mengandung elemen 'keharusan', maka norma memberikan justifikasi atas tindakan yang diambil suatu negara (Finnemore \& Sikkink 1998, 892). Di lain pihak, negara yang melakukan tindakan di luar norma internasional dianggap menyimpang (deviant), oleh karena itu negara bersangkutan menempel identitas sebagai negara jahat, tiran, tidak beradab, dan seterusnya. Bagi konstruktivis norma bukan sekadar alat kepentingan negara sebagaimana dikatakan kaum realis melainkan struktur sosial yang membatasi pilihan kebijakan negara (Rosyidin 2015, 75). Negara patuh terhadap norma bukan semata-mata untuk memperoleh keuntungan material berjangka pendek tetapi karena norma tersebut dimaknai secara positif sebagai instrumen keteraturan masyarakat internasional.

Dalam isu intervensi kemanusiaan, standar perilaku yang menjustifikasi negara melakukan tindakan intervensi adalah norma yang termaktub dalam Piagam PBB tentang hak asasi manusia. Norma hak asasi manusia yang relevan di sini pada intinya berisi hak untuk hidup, yaitu "hak bebas dari penghilangan nyawa dan hukuman tanpa pengadilan serta bebas dari penganiayaan dan penangkapan yang semena-mena" (Risse \& Sikkink dalam Risse, Ropp \& Sikkink 1999, 2). Norma kemanusian ini berlaku sebagai 'principled beliefs' (Goldstein \& Keohane 1993, 43). yang berfungsi memberi makna dan kategorisasi tindakan yang baik atau buruk dan adil atau tidak adil. Institusi ini adalah struktur normatif yang menuntun aktor internasional untuk tunduk dan patuh kepada aturan legal-formal tersebut. Pada perkembangan selanjutnya, norma internasional yang mendasari intervensi kemanusiaan adalah prinsip Responsibility to Protect (R2P). Prinsip etis ini sebenarnya muncul lantaran dunia internasional tidak mampu berbuat apa-apa ketika menghadapi genosida di Bosnia dan Rwanda pada paruh pertama dekade 1990-an. Kofi Annan, mantan Sekretaris Jenderal PBB menulis di The Economist bahwa kedaulatan bermakna tanggung jawab; tanggung jawab melindungi warga negaranya dari kejahatan kemanusiaan. Apabila pemerintah suatu negara gagal menjalankan kewajiban ini, maka dunia internasional akan mengambil alih kewajiban itu, yang artinya melakukan intervensi (Annan 1999). Menurutnya, kedaulatan harus dipahami sebagai sesuatu hal yang bersyarat (tidak mutlak) sejauh pemerintah menghormati hak asasi warga negaranya (Annan 2012, 84).

Intervensi kemanusiaan baik dilakukan negara individual maupun multilateral bertujuan membela nilai-nilai luhur yang disepakati bersama yaitu hak asasi manusia. Negara dalam konteks ini adalah 'aktor publik' (Lu 2006). Tindakan negara dimotivasi oleh 'barang publik' dan oleh karena itu negara bersifat altruis (tidak mementingkan diri sendiri). Kepentingan nasional yang diterjemahkan ke dalam 
kepentingan internasional merupakan manifestasi altruisme negara. Organ internasional dalam hal ini DK PBB berperan seperti penegak hukum yang menjaga aturan dan norma internasional itu tetap dipatuhi. Pelanggaran terhadap norma internasional tadi sama artinya mengancam perdamaian dan keamanan dunia. Oleh karena itu harus diberikan tindakan untuk menghukum si pelanggar. Pemberian sanksi dijustifikasi karena demi terwujudnya kebaikan bersama. Bagi penganut konstruktivis, studi tentang intervensi kemanusiaan adalah studi tentang justifikasi. Ketika suatu negara menjustifikasi intervensi yang ia lakukan, berarti negara itu telah mendapatkan legitimasi dan mengartikulasikan nilai-nilai dan harapan bersama dunia internasional (Finnemore dalam Katzenstein 1996, 156).

Penjelasan konstruktivisme yang melihat negara sebagai aktor yang memperjuangkan kepentingan publik yakni menegakkan norma internasional bisa kita cermati dalam kasus intervensi kemanusiaan Amerika Serikat di Somalia pada 1992. Dalam operasi militer bersandi Operation Restore Hope yang berlangsung selama tiga tahun itu, Amerika Serikat memasuki wilayah yurisdiksi Somalia untuk menunaikan misi kemanusiaan dan 'nation building'. Seperti dinyatakan Finnemore (dalam Katzenstein 1996b), intervensi di Somalia bukan didasari oleh motif kepentingan karena Somalia bukanlan negara yang dapat memberikan keuntungan (baik politik, ekonomi, maupun militer) bagi Amerika Serikat. Sebaliknya, Somalia adalah negara kolaps yang didera pertikaian politik primordial akut, sehingga membawa kesengsaraan rakyat sipil. Dalam sebuah dokumen resmi pemerintah Amerika Serikat bertanggal 7 Desember 1992, dikatakan bahwa sebagai anggota tetap DK PBB Amerika Serikat mengintervensi Somalia bukan untuk memperjuangkan kepentingan nasionalnya melainkan tekanan domestik berupa 'desakan moral' untuk membantu rakyat Somalia, khususnya anak-anak (Sarbu 2009, 15). Pembunuhan rakyat sipil merajalela menyebabkan gelombang pengungsi ke negara tetangga seperti Kenya, Ethiopia dan Djibouti. Kelaparan parah akibat bantuan pangan dari lembaga internasional disabotase oleh para milisi untuk memberi makan tentara atau menukarkannya dengan senjata (Hippel 2004, 3). Di sini, Amerika Serikat berperan seperti sang Mesias atau juru selamat bagi rakyat Somalia, jadi bukan datang untuk mencari keuntungan-keuntungan jangka pendek.

Kasus lain misalnya pada saat terjadi konflik Serbia-Bosnia di Yugoslavia antara tahun 1993-1995. Konflik bernuansa SARA memicu perpecahan politik di Balkan (debalkananisasi) yang kemudian diikuti dengan genosida besar-besaran. Slobodan Milosevic yang chauvinistik dari Serbia melakukan pembersihan etnis Bosnia di Srebrenica. Pada 1995. NATO menggempur Sarajevo dengan operasi militer bersandi Operation Deliberate Force untuk memburu Slobodan Milosevic dan Radovan Karadzic yang dianggap paling bertanggung jawab atas 
pembantaian warga sipil Bosnia. Intervensi Amerika Serikat di Bosnia adalah upaya untuk menegakkan norma hak asasi manusia yang dilanggar oleh rezim tiran dan berdarah dingin. Intervensi kemanusiaan di Bosnia dan Kosovo paling tidak menunjukkan komitmen komunitas internasional untuk menanggapi pelanggaran hak asasi manusia berat di negara itu (Morris dalam Welsh 2004, 99). Sama seperti Somalia, kawasan Balkan tidak terlalu menguntungkan bagi Amerika Serikat secara ekonomis maupun strategis. Balkan adalah wilayah yang terfragmentasi berdasarkan identitas etnis dan agama. Setelah Amerika Serikat angkat kaki dari Bosnia, kini wilayah itu terbagi-bagi menjadi beberapa negara independen yakni Macedonia, Slovenia, Kroasia, Bosnia, dan Serbia-Montenegro.

\section{Simpulan}

Sejarah intervensi kemanusiaan adalah sejarah penaklukan. Intervensi kemanusiaan sebenarnya tidak jauh berbeda dengan perang untuk menaklukkan negara lain. Hanya saja, letak perbedaannya adalah apakah negara memasuki wilayah kedaulatan negara lain tanpa ijin tuan rumah tersebut dilatarbelakangi oleh motif mementingkan orang banyak ataukah mementingkan diri sendiri. Dalam hal ini, realis menganggap konsep intervensi kemanusiaan sebagai sebuah oxymoron atau contradiction in terminis. Alasannya, realis mengasumsikan hubungan internasional adalah arena perjuangan mengejar kepentingan nasional, bukan kepentingan kemanusiaan. Sebagaimana telah dijelaskan di bagian kedua tulisan ini, realis menegaskan bahwa intervensi kemanusiaan terjadi hanya jika negara pengintervensi melihat ada kepentingan nasional atau keuntungan yang bisa diraih. Alhasil, cara pandang realis yang murni politis tersebut cenderung berlawanan dengan konsep intervensi kemanusiaan menurut hukum internasional yang menempatkan penegakan hak asasi manusia sebagai tujuan dasar dilakukannya intervensi kemanusiaan. Dengan demikian, realis merancukan definisi intervensi kemanusiaan dengan intervensi militer atau agresi. Dengan adanya pandangan bahwa tidak ada istilah 'kemanusiaan' dalam kamus hubungan internasional kaum realis, maka boleh dikatakan bahwa realis hanya menggunakan istilah intervensi kemanusiaan sebagai dalih melakukan agresi.

Hal ini berbeda dengan cara pandang konstruktivis yang mengakui adanya unsur kemanusiaan dalam sebuah aksi militer ke negara lain. Bagi konstruktivis, norma-norma internasional lebih mempengaruhi tindakan negara ketimbang dorongan kepentingan nasional. Berbeda dengan realis yang menganggap kepentingan nasional sebagai 'the only game in town', konstruktivis justru menganggap kepentingan nasional adalah derivasi dari norma-norma internasional. Alhasil, intervensi 
kemanusiaan dipandang kaum konstruktivis sebagai bentuk kepatuhan negara pengintervensi terhadap norma-norma internasional tersebut. Konsep sentral norma ini berimplikasi pada asumsi bahwa negara pengintervensi mengusung misi altruis ketika memutuskan terjun ke medan perang, yaitu menyelamatkan nyawa warga negara lain yang terancam oleh kekejaman pemerintahnya. Sebagaimana telah dipaparkan di bagian keempat dari tulisan ini, pandangan konstruktivis ini sejalan dengan konsepsi R2P yang secara eksplisit memuat unsur moralitas di dalamnya. Prinsip dasar R2P yakni komunitas internasional - dalam hal ini negara - memikul tanggung jawab untuk menegakkan norma hak asasi manusia di negara lain jika pemerintah di negara bersangkutan gagal menegakkannya merepresentasikan komitmen moral negara yang konsisten dengan premis konstruktivis. Jadi, jika kaum realis memperlakukan intervensi kemanusiaan sebatas sebagai kedok melakukan agresi demi mengejar kepentingan nasional, kaum konstruktivis melihat bahwa perang sekalipun terkadang ada unsur moralitasnya.

Kritik yang kerapkali muncul mengenai praktik intervensi kemanusiaan adalah ekses negatif yang ditimbulkannya. Sekalipun pada awalnya intervensi kemanusiaan dimotivasi oleh penegakan hak asasi manusia entah sebagai dalih agresi maupun tujuan sebenarnya - namun kenyataannya yang terjadi malah sebaliknya. Warga sipil yang ingin dilindungi justru banyak menjadi korban. Hal ini mungkin saja akibat ketidaksengajaan atau collateral damage. Namun, seperti telah disebutkan sebelumnya, intervensi kemanusiaan adalah sebuah paradoks. Amat sulit memastikan tujuan awal tidak melenceng dari batas-batas moralitas. Fakta-fakta menunjukkan kalau intervensi kemanusiaan selalu diiringi dengan jatuhnya korban jiwa warga sipil yang tidak sedikit jumlahnya. Dalam hal ini konsep R2P yang dirancang secara lebih komprehensif - mensyaratkan adanya tanggung jawab merekonstruksi (responsibility to build) - juga tidak efektif karena bukannya menciptakan stabilitas keamanan jangka panjang melainkan justru menciptakan kekacauan baru. Munculnya kelompok-kelompok militan di Timur Tengah salah satunya dipicu oleh intervensi militer negara-negara Barat yang mulanya diklaim dimaksudkan untuk menegakkan hak asasi manusia. Komunitas internasional perlu mencari formula yang lebih tepat bagaimana mencegah ekses-ekses negatif dari pelaksanaan intervensi kemanusiaan.

\section{Daftar Pustaka}

\section{Buku}


Annan, Kofi, 2012. Intervention: A Life in War and Peace. New York: Penguin.

Bellamy, Alex dan Nicholas Wheeler, 1998. "Humanitarian Intervention in World Politics", dalam Baylis, John dan Steve Smith (eds), 1998. The Globalization of World Politics: An Introduction to International Relations. New York: Oxford University Press.

Baylis, John and Steve Smith, eds. 1998. The Globalization of World Politics: An Introduction to International Relations. New York: Oxford University Press.

Bellamy, Alex, 2008. "The Responsibility to Protect", dalam Williams, Paul (ed.), 2008. Security Studies: An Introduction. London: Routledge.

Blum, William, 2002. Rogue State: A Guide to the World's Only Superpower. London: Zed Books.

Buzan, Barry dan Lene Hansen, 2009. The Evolution of International Security Studies. Cambridge: Cambridge University Press.

Buzan, Barry Ole Waever dan Jaap de Wilde, 1998. Security: A New Framework of Analysis. Boulder: Lynne Rienner.

Buzan, Barry, 1991. People, States and Fear: An Agenda for International Security Studies in the Post-Cold War Era. Boulder: Lynne Rienner Publishers.

Donnelly, Jack, 2000. Realism and International Relations. Cambridge: Cambridge University Press.

Finnemore, Martha, 1996a. National Interest in International Society. Ithaca: Cornell University Press.

Finnemore, Martha, 1996b. "Constructing Norms of Humanitarian Intervention", dalam Katzenstein, Peter (ed), 1996. The Culture of National Security: Norms and Identity in World Politics. New York: Columbia University Press.

Finnemore, Martha, 2003. The Purpose of Intervention: Changing Beliefs about the Use of Force. Ithaca: Cornell University Press.

Finnemore, Martha, 2008. "Paradoxes in Humanitarian Intervention", dalam Price, Richard (ed.), 2008. Moral Limit and Possibility in World Politics. Cambridge: Cambridge University Press.

Fukuyama, Francis, 1992. The End of History and the Last Man. New York: Free Press.

Fukuyama, Francis, 2006. America at the Crossroads: Democracy, Power, and the Neoconservative Legacy. New Haven: Yale University Press.

Goldstein, Judith dan Robert Keohane, 1993. "Ideas and Foreign Policy: An Analytical Framework", dalam Goldstein, Judith dan Robert Keohane (eds), 1993. Ideas and Foreign Policy: Beliefs, Institutions, and Political Change. Ithaca: Cornell University Press. 
Hehir, Aidan, 2010. Humanitarian Intervention: An Introduction. New York: Palgrave Macmillan.

Heinze, Eric, 2009. Waging Humanitarian War: The Ethics, Law, and Politics of Humanitarian Intervention. Albany: State University of New York Press.

Hippel, Karin von, 2004. Democracy by Force:US Military Intervention in the Post-Cold War World. Cambridge: Cambridge University Press.

Holzgrefe, J. L, 2003. "The Humanitarian Intervention Debate", dalam Holzgrefe, J. L. dan Robert Keohane (eds), 2003. Humanitarian Intervention: Ethical, Legal, and Political Dilemmas. Cambridge: Cambridge University Press.

Holzgrefe, J. L. dan Robert Keohane (eds), 2003. Humanitarian Intervention: Ethical, Legal, and Political Dilemmas. Cambridge: Cambridge University Press.

Katzenstein, Peter (ed), 1996. The Culture of National Security: Norms and Identity in World Politics. New York: Columbia University Press.

Kissinger, Henry, 1994. Diplomacy. New York: Simon-Schuster.

Krieg, Andreas, 2013. Motivations for Humanitarian Intervention: Theoretical and Empirical Considerations. London: Springer.

$\mathrm{Lu}$, Catherine, 2006. Just and Unjust Interventions in World Politics Public and Private. London: Palgrave Macmillan.

Lynn-Jones, Sean, 1991. International Security Studies after the Cold War: An Agenda for the Future. CSIA Discussion Paper 91-11, Kennedy School of Government, Harvard University, December.

March, James dan Johan Olsen, 2004. "The Logic of Appropriateness", ARENA Working Papers, WP 04/o9.

Morgenthau, Hans, 1954. Politics Among Nations: The Struggle for Power and Peace, $2^{\text {nd }}$ edn. New York: Alfred A. Knopf.

Morris, Nicholas, 2004. "Humanitarian Intervention in the Balkans", dalam Welsh, Jennifer (ed), 2004. Humanitarian Intervention and International Relations. New York: Oxford University Press.

Nardin, Terry, 2000. The Moral Basis of Humanitarian Intervention. Symposium on the Norms and Ethics of Humanitarian Intervention, Center for Global Peace and Conflict Studies, University of California, Irvine, May 26.

Onuf, Nicholas, 2000. Humanitarian Intervention: The Early Years. Symposium on the Norms and Ethics of Humanitarian Intervention, Center for Global Peace and Conflict Studies, University of California, Irvine, May 26.

Price, Richard (ed), 2008. Moral Limit and Possibility in World Politics. Cambridge: Cambridge University Press.

Risse, Thomas dan Kathryn Sikkink, 1999. "The Socialization of International Human Rights Norms into Domestic Practices: Introduction", dalam Risse, Thomas, Stephen Ropp dan Kathryn 
Sikkink (eds), 1999. The Power of Human Rights: International Norms and Domestic Change. Cambridge: Cambridge University Press.

Risse, Thomas, Stephen Ropp dan Kathryn Sikkink (eds), 1999. The Power of Human Rights: International Norms and Domestic Change. Cambridge: Cambridge University Press.

Rosyidin, Mohamad, 2015. The Power of Ideas: Konstruktivisme dalam Studi Hubungan Internasional. Yogyakarta: Tiara Wacana.

Sarbu, Bianca, 2009. Drivers of the UN Humanitarian Interventions: Going Beyond Human Rights Violations, Tesis MA, The Swiss Federal Institute of Technology Zurich.

Shue, Henry, 2004. "Limiting Sovereignty", dalam Welsh, Jennifer (ed), Humanitarian Intervention and International Relations. New York: Oxford University Press.

Waltz, Kenneth, 1979. Theory of International Politics. Reading, MA: Addison Wesley.

Welsh, Jennifer (ed), 2004. Humanitarian Intervention and International Relations. New York: Oxford University Press.

Wendt, Alexander, 1999. Social Theory of International Politics. Cambridge: Cambridge University Press.

Wheeler, Nicholas, 2000. Saving Strangers: Humanitarian Intervention in International Society. New York: Oxford University Press.

Wheeler, Nicholas, 2004. "The Humanitarian Responsibilities of Sovereignty: Explaining the Development of a New Norm of Military Intervention for Humanitarian Purposes in International Society", dalam Welsh, Jennifer (ed), Humanitarian Intervention and International Relations. New York: Oxford University Press.

Williams, Paul (ed), 2008. Security Studies: An Introduction. London: Routledge.

Zehfuss, Maja, 2004. Constructivism In International Relations: The Politics of Reality. Cambridge: Cambridge University Press.

\section{Jurnal}

Bellamy, Alex, 2003. "Humanitarian Intervention and the Three Traditions", Global Society, 17(1): 3-20.

Finnemore, Martha dan Kathryn Sikkink, 1998. "International Norm Dynamics and Political Change",International Organization, 52(4): 887-917.

Jervis, Robert, 2003. "Understanding the Bush Doctrine", Political Science Quarterly, 118(3): 365-388.

Kolodziej, Edward, 1992. "Renaissance in Security Studies? Caveat Lector!" International Studies Quarterly, 36(4): 421-438. 
Monten, Jonathan, 2005. "The Roots of the Bush Doctrine: Power, Nationalism, and Democracy Promotion in US Strategy", International Security, 29(4): 112-156.

Morgenthau, Hans, 1967. "To Intervene or Not To Intervene", Foreign Affairs, 45(3): 425-436.

Rice, Condoleezza, 2008. "Rethinking the National Interest: American Realism for a New World", Foreign Affairs, 87(4): 2-26.

Walt, Stephen, 1991. "The Renaissance of Security Studies", International Studies Quarterly, 35(2): 211-239.

Wendt, Alexander, 1992. "Anarchy is What States Make of It: The Social Construction of Power Politics", International Organization, 46(2): 391-425.

\section{Artikel online}

Antara News, 2011. "TV Libya: serangan NATO tewaskan 16 warga sipil di Brega" [online]. Dalam http://www.antaranews.com/berita/258515/tv-libya-serangannato-tewaskan-16-warga-sipil-di-brega [diakses 30 Mei 2011].

Republika, 2011. "NATO tolak tawaran negosiasi Qaddafi" [online]. Dalam

http://www.republika.co.id/berita/internasional/global/11/o4/3 o/lkh36c-nato-tolak-tawaran-negosiasi-qaddafi [diakses 30 Mei 2011].

Viva News, 2011. "Amerika dan sekutu serang Libya" [online]. Dalam http://fokus.vivanews.com/news/read/210464-sekutu-serbulibya [diakses 30 Mei 2011].

\section{Majalah}

Annan, Kofi, 1999. "Two Concepts of Sovereignty", The Economist, 19 September. 